\title{
Both high and low levels of cellular Epstein-Barr virus DNA in blood identify failure after hematologic stem cell transplantation in conjunction with acute GVHD and type of conditioning
}

\author{
Qin Li ${ }^{1}$, Lalit Rane ${ }^{1}$, Thomas Poiret ${ }^{2}$, Jiezhi Zou ${ }^{1}$, Isabelle Magalhaes ${ }^{3}$, Raija \\ Ahmed ${ }^{4}$, Ziming Du${ }^{5}$, Nalini Vudattu6 ${ }^{6}$ Qingda Meng ${ }^{2}$, Åsa Gustafsson-Jernberg7, \\ Jacek Winiarski ${ }^{7,9}$, Olle Ringdénn ${ }^{2,8}$, Markus Maeurer ${ }^{2,8}$, Mats Remberger $^{2,8}$ and \\ Ingemar Ernberg ${ }^{1}$ \\ ${ }^{1}$ Department of Microbiology, Tumor and Cell Biology (MTC), Karolinska Institutet, Stockholm, Sweden \\ ${ }^{2}$ Division of Therapeutic Immunology, Labmed, Karolinska University Hospital, Huddinge, Stockholm, Sweden \\ ${ }^{3}$ Department of Oncology-Pathology (OnkPat), Karolinska University Hospital, Stockholm, Sweden \\ ${ }^{4}$ Public Health Agency, Solna, Sweden \\ ${ }^{5}$ Division of Neuropathology, Department of Pathology, Brigham and Women's Hospital, Harvard Medical School, Boston, \\ MA, USA \\ ${ }^{6}$ Department of Immunobiology and Internal Medicine, Yale University, New Haven, CT, USA \\ 7 Department of Clinical Science, Intervention an Technology (CLINTECH), Karolinska University Hospital, Huddinge, \\ Stockholm, Sweden \\ ${ }^{8}$ Center for Allogeneic Stem Cell Transplantation, Karolinska University Hospital, Huddinge, Stockholm, Sweden \\ ${ }^{9}$ Department of Pediatrics, Karolinska University Hospital, Huddinge, Stockholm, Sweden \\ Correspondence to: Ingemar Ernberg, email: ingemar.ernberg@ki.se
}

Keywords: stem cell transplantation, EBV DNA-load, T-cell phenotype, total body irradiation, aGVHD, Immunology and Microbiology Section, Immune response, Immunity

Received: March 04, $2016 \quad$ Accepted: April 11, 2016

Published: April 19, 2016

\section{ABSTRACT}

The level of Epstein-Barr virus DNA in blood has proven to be a biomarker with some predictive value in allogeneic hematopoietic stem cell transplantation patients (HSCT). We evaluated the impact of EBV load on survival of 51 patients (32M/19F, median age: 32 years, from < 1 to 68 years old), who had received HSCT for different types of malignancies ( 49 cases) or non-malignancies ( 2 cases). The overall survival [1] was compared between patients with extreme and moderate cell bound EBV DNA levels. Different sources of stem-cells (peripheral blood stem, $n=39$; bone marrow, $n=9$; or umbilical cord blood, $n=3$ ) were used. Twenty patients received reducedintensity conditioning regimen while the other 31 received myeloablative conditioning. Patients with high or very low level of cell bound EBV-DNA levels had a shorter OS than those with moderate EBV load: OS at 5 years was $67 \%$ vs $90 \%(p<0.03)$. There was a conspicuous relationship between EBV load and the reconstitution dynamics of total and EBV-specific T cells, CD4+ and CD4- CD8- (double negative) T cells in the few patients where it was analyzed. This was not statistically significant. Two other factors were associated to early mortality in addition to high or low EBV load: acute GVHD II-IV $(p<0.02)$ and pre-transplant conditioning with total body irradiation (TBI) $\geq 6 \mathrm{~Gy},(p<0.03)$. All the patients meeting all three criteria died within two years after transplantation. This points to a subgroup of HSCT patients which deserve special attention with improvement of future, personalized treatment. 


\section{INTRODUCTION}

Patients receiving bone marrow (BMT) or hematologic stem cell transplants (HSCT) show a considerable risk to develop EBV-associated posttransplant lymphoproliferative disorder (PTLD) and lymphomas [1]. The following risk-factors have been associated with EBV-related complications after HSCT: HLA and EBV mismatch between recipient and donor, reduced intensity conditioning (RIC), acute graft-versushost disease (GVHD) and pre-transplant splenectomy [2]. PTLD may be prevented or even cured by administration of donor derived EBV-specific cytotoxic T lymphocytes [3, 4]. Thus, imbalance in the control of the persistent, latent EBV-infection is one major factor in the pathogenesis of these complications.

Epstein-Barr virus (EBV) is a gamma herpesvirus with the unique capacity to establish latent infection in human B lymphocytes and also to activate them into proliferating lymphoblasts, acting thereby as a predisposing factor for different types of B-cell malignancies $[5,6]$. Primary EBV infection is widely spread and results in lifelong latent infection in more than $90 \%$ of immunocompetent adults worldwide [7, 8]. Viral proteins expressed in the latently infected B-cells serve as targets for strong T-cell mediated rejection responses, that can limit the proliferation of EBV carrying lymphoblasts [9]. In addition it has been demonstrated that helper CD4+ $\mathrm{T}$ lymphocytes can play an instrumental role in controlling the EBV-latency [10].

Multiple evidence points to an important role of EBV-specific T-cells in the long term control of the EBV carrier state. Failure of this control leads to the occurrence of EBV positive lymphomas in immunosuppressed patients after transplantation and as a late, severe AIDSdetermining outcome of HIV infection [11, 12]. We can better understand the critical components of immunity controlling EBV by studying the dynamics of the immune reconstitution during the post-HSCT period. Together with EBV-DNA load as measured in blood features of this reconstitution may provide more precise predictive tools in guiding the post-transplant therapeutic strategy.

EBV DNA levels in blood reflect the intricate and complex balance between EBV and the host, including both EBV replication, the host response to the virus and to virus-infected cells. After transplantation the levels of EBV DNA-load in blood is affected both by immunosuppressive treatment and immune stimulatory mechanisms, like acute graft-versus host disease [13, 14]. In BMT-/HSCT-patients the EBV-genomes are predominantly detected in the virus carrying B-lymphocytes, while cell free EBV-DNA in blood/plasma is more rare $[14,15]$. In organ transplanted patients and cancer patients also, cell free EBV-DNA can be useful for clinical predictions [16, 17]. After organtransplantation rapidly rising EBV DNA-levels can reflect or even predict severe complications [18-20]. The predictive value of EBV DNA-load for patient outcome is well-documented in transplanted patients [4, 21]. In BMT and HSCT-patients very high levels of EBV DNA can be detected after certain conditioning, e.g. treatment with anti-thymocyte globulin (ATG) [4], which is also associated with higher risk for PTLD and other adverse complications [16]. The EBV status has been claimed to be of limited value as predictive marker of treatment response in adults with PTLD [22]. The literature is partly confounded by the mix of using non -cell-bound (in plasma) and cell-bound EBV-DNA. For patient follow up or decisions on treatment in individual patients the EBV DNA load has so far been of limited value.

In a clinical follow-up project we determined EBV load and immune parameters in HSCT patients by regular sampling during one year after transplantation. We found a strong prognostic value of predefined levels of EBV DNA load. Patients with very low or high levels of cell bound EBV-DNA in blood early after transplantation showed a poor prognosis, compared to patients with intermediate levels. When combined with two other risk factors, severe acute GVHD (aGVHD II-IV) and conditioning with high dose total body irradiation (TBI) none of these patients survived more than two years after transplantation.

\section{RESULTS}

\section{Grouping of patients based on EBV DNA load}

The EBV genome load in PBMC was followed for 12 months post transplantation. The EBV load values during the first three months were used as the basis for assigning the patients to either of two groups.

Thirty of the 51 patients (60\%) were assigned to the $\mathrm{EBV}_{\text {high+low }}$ group, according to our definition. Twenty-one patients $(40 \%)$ belong to the $\mathrm{EBV}_{\text {intermediate }}$ group. There were no difference in clinical parameters between these two groups (Table 1).

\section{Overall survival of patients in the two EBV groups}

The $\mathrm{EBV}_{\text {hightlow }}$ patients had a lower overall survival rate than those in the $\mathrm{EBV}_{\text {intermediate }}$ group (Figure 1; $p=$ $0.03)$. OS at 5 years was $67 \%$ vs $90 \%,(P<0.03)$.

\section{Risk factors, survival and cause of death}

Three factors significantly or close to significantly correlated to mortality in the univariate analysis $(P<0.10$; Table 2). Another three factors (with $P<0.20$ ) were also identified by multivariate analysis. In the final combined multivariate analysis three factors were associated to 
Table 1: Characteristics of patients and donors.

\begin{tabular}{|l|l|l|l|l|}
\hline & Whole population & High+Low & Intermediate & $p$-value \\
\hline $\boldsymbol{N}=$ & 51 & 30 & 21 & \\
\hline Age & $32(<1-68)$ & $32(<1-68)$ & $34(7-68)$ & 0.67 \\
\hline Children $(<18 y)$ & 17 & $9(30 \%)$ & $8(38 \%)$ & 0.56 \\
\hline Sex (M/F) & $32 / 19$ & $21 / 9$ & $11 / 10$ & 0.25 \\
\hline $\begin{array}{l}\text { Malignancy/Non- } \\
\text { Malignancy }\end{array}$ & $49 / 2$ & $28 / 2$ & $21 / 0$ & 0.50 \\
\hline Stage (early/late) & $22 / 29$ & $12 / 18$ & $10 / 11$ & 0.77 \\
\hline Donor: & & & & \\
\hline Sibling/MUD/MM & $12 / 32 / 7$ & $6 / 19 / 5$ & $6 / 13 / 2$ & 0.37 \\
\hline Donor age & $30(0-62)$ & $30(0-62)$ & $28(13-57)$ & 0.98 \\
\hline Conditioning: & & & & \\
\hline MAC/RIC & $31 / 20$ & $15 / 15$ & $16 / 5$ & 0.08 \\
\hline TBI $\geq 6$ Gy & 17 & $10(33 \%)$ & $7(33 \%)$ & 1.00 \\
\hline ATG & 37 & $21(70 \%)$ & $16(76 \%)$ & 0.75 \\
\hline GVHD prophylaxis: & & & & \\
\hline CsA+MTX/other & $33 / 18$ & $17 / 13$ & $16 / 5$ & 0.23 \\
\hline Stem-Cell source: & & & & \\
\hline BM/PBSC/CB & $9 / 39 / 3$ & $2 / 25 / 3$ & $7 / 14 / 0$ & 0.28 \\
\hline $\begin{array}{l}\text { CD34+ cell dose }\left(x 10^{6} /\right. \\
\text { kg) }\end{array}$ & & $7.1(0.1-28.2)$ & $5.5(1.8-22.8)$ & 0.55 \\
\hline CMV sero neg/neg & 9 & 4 & 5 & 0.46 \\
\hline EBV sero-MM & 4 & 3 & 1 & 0.63 \\
\hline aGVHD 0-I/II-IV & $23 / 28$ & $15 / 15$ & $8 / 13$ & 0.26 \\
\hline Folow-up (months) & $75(42-103)$ & $57(42-103)$ & $86(44-99)$ & 0.25 \\
\hline
\end{tabular}

Early stage; CR1/CP1 or non-malignant disorder, Late stage; beyond CR1/CP1, MUD; matched unrelated donor, MM; mismatched donor, MAC; myeloablative conditioning, RIC; reduced intensity conditioning, CsA; cyclosporine, MTX; methotrexate, BM; bone marrow, PBSC; peripheral-blood stem cells, CB; cord blood, CMV sero neg/neg; cytomegalovirus pre-SCT serological negative donor and recipient, EBV sero-MM; serological mismatch between donor and recipient, aGVHD; acute graft-versus-host disease.

mortality: high+low EBV DNA load, acute GVHD II-IV and conditioning with $\mathrm{TBI} \geq 6$ Gy (Table 2 )

Combined analysis of these risk factors showed that of the 51 patients, those with none of the risk factors $(0$ $\mathrm{RF}, n=7$ ) showed a survival rate of $100 \%$; those with one $(n=18)$ had a survival rate of $83 \%$, with two risk factors $(n=21) 81 \%$ and those with all three risk factors $(n=5)$ showed the worst survival rate, $0 \%$ (Figure 2 ). In addition to the patient group with high or low EBV load $(n=30)$ which by definition had at least one risk factor, 15 patients had two risk factors and five all three risk factors. In the $\mathrm{EBV}_{\text {intermediate }}$ patient group, seven patients had no risk factor $(7 / 21)$, eight had one and six had two risk factors $(6 / 21)$. The causes of death $(n=2)$ in the $\mathrm{EBV}_{\text {intermediate }}$ patients were bacterial infection $(1 / 21)$ and cGVHD $(1 / 21)$. The causes of death $(n=11)$ in the $\mathrm{EBV}_{\text {high+low }}$ group were specifically relapse $(n=4)$, bacterial infection $(n=$ $3)$, organ failure ( $n=3$, one also with bacterial infection), acute $\operatorname{GVHD}(n=1)$ and a secondary malignancy $(n=1$, not EBV related).

\section{Dynamics of immune reconstitution in the two EBV load groups}

In fourteen of the patients we performed follow up of cellular immune parameters. The analysis included frequency of CD3+ T-cells, CD4+ cells, CD8+cells, Treg cells (CD3+/CD4+/CD4+CD25hi+/Foxp3+/CD127-) and CD4-negative/CD8-negative cells (double negatives, DN). Seven of these patients belonged to the $\mathrm{EBV}_{\text {intermediate }}$ group and seven to the $\mathrm{EBV}_{\text {high+low }}\left(5\right.$ in $\mathrm{EBV}_{\text {low }}$ group and 2 in $\mathrm{EBV}_{\text {high }}$ group).

During the first three months after transplantation, the patients in the $\mathrm{EBV}_{\text {low }}$ group showed high levels of $\mathrm{T}$ lymphocytes, above or around $60 \%$. In contrast, the two patients with high EBV load showed low CD3+ frequency during the first 3 months, below $60 \%$ with the lowest around $20 \%$. The $\mathrm{EBV}_{\text {intermediate }}$ group had a CD3+ frequency between $30 \%$ to $70 \%$ (Figure 3 ).

The frequency of CD4+ T-cells in the $\mathrm{EBV}_{\text {low }}$ group was also relatively high, mostly above $30 \%$, while those 
Table 2: Univariate and multivariate analysis of factors associated to Mortality.

\begin{tabular}{|l|l|l|l|}
\hline Factor & HR & $\boldsymbol{p}$-value & Multivariate \\
\hline Intermediate EBV response & 0.22 & 0.03 & $0.12,0.02-0.59,<0.01$ \\
\hline Age & 1.02 & 0.17 & \\
\hline Sibling donor & 0.87 & 0.84 & \\
\hline CsA+MTX & 1.16 & 0.80 & \\
\hline Late stage & 0.58 & 0.33 & \\
\hline CD34+ cell-dose & 1.00 & 0.84 & \\
\hline Donor age & 1.03 & 0.17 & \\
\hline RIC & 0.97 & 0.96 & \\
\hline ATG & 1.40 & 0.61 & \\
\hline aGVHD II-IV & 3.27 & 0.07 & $4.72,1.25-17.8,0.02$ \\
\hline PBSC & 1.01 & 0.98 & \\
\hline CMV sero neg/neg & 0.93 & 0.92 & \\
\hline EBV sero-MM & 2.82 & 0.18 & \\
\hline TBI $\geq 6$ Gy & 2.61 & 0.08 & $3.55,1.13-11.1,0.03$ \\
\hline
\end{tabular}

In the multivariate analysis $\mathrm{HR}, 95 \%$ confidence interval and p-value are presented.

Late stage; beyond CR1/CP1, RIC; reduced intencity conditioning, CsA; cyclosporine, MTX; methotrexate, PBSC; peripheralblood stem cells, CMV sero neg/neg; cytomegalovirus pre-SCT serological negative donor and recipient, EBV sero-MM; serological mismatch between donor and recipient. TBI $\geq 6$ Gy; total-body irradiation $\geq 6$ Gy.

in the $\mathrm{EBV}_{\text {intermediate }}$ group predominantly showed CD4+ levels below 30\% (Figure 3). Although the individual variation of $\mathrm{T}_{\text {reg }}$ levels was considerable, the groups with high or intermediate EBV loads and lower CD4+ had a higher proportion of Tregs. While the levels of EBV load inversely related to total CD3 and CD4 levels, as for DNs we could detect such a relation only at one month but not later (Figure 3).

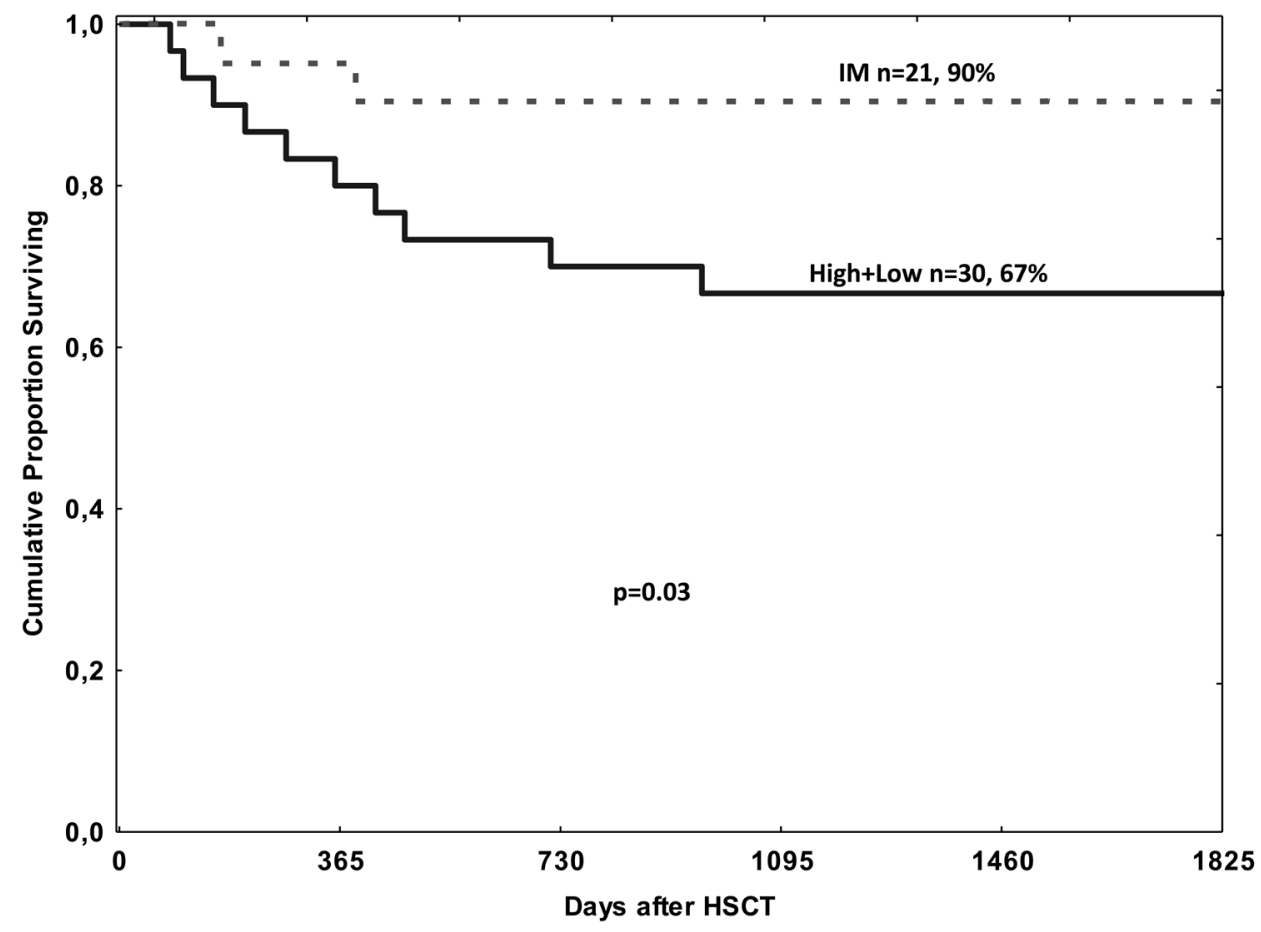

Figure 1: Overall survival depending on EBV DNA levels after HSCT. EBV DNA levels were classified into two groups: intermediate (IM) $(n=21)$ or high + low $(n=30)$. The overall survival rates were $90 \%$ in EBV intermediate group and $67 \%$ in EBV high+low group, respectively; there was a significant difference in the overall survival rate between the two groups $(p=0.03)$. 


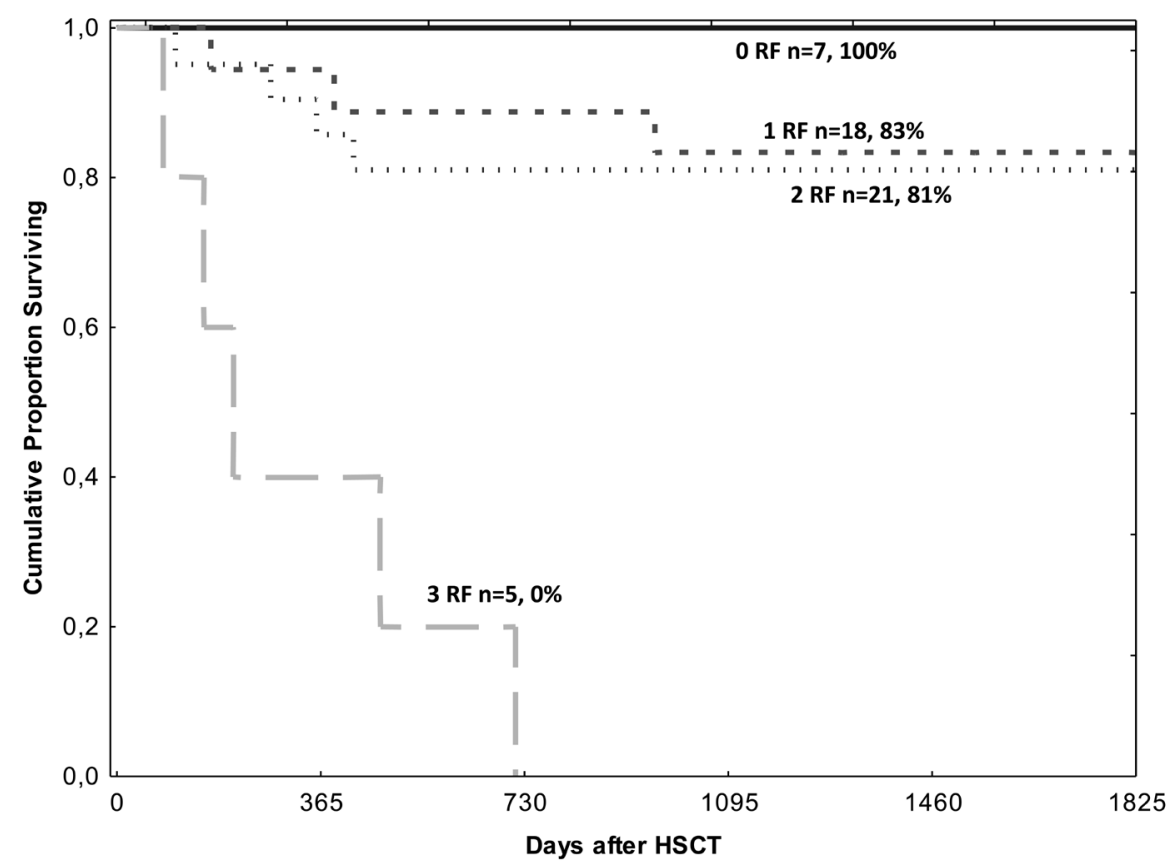

Figure 2: Overall survival after HSCT in patients without $(n=7)$, with one $(n=18)$, two $(n=21)$ and three $(n=5)$ of the risk-factors found in the multivariate analysis. The risk-factors were: EBV DNA load low + high, acute GVHD II-IV and conditioning containing $\mathrm{TBI} \geq 6 \mathrm{~Gy}$.
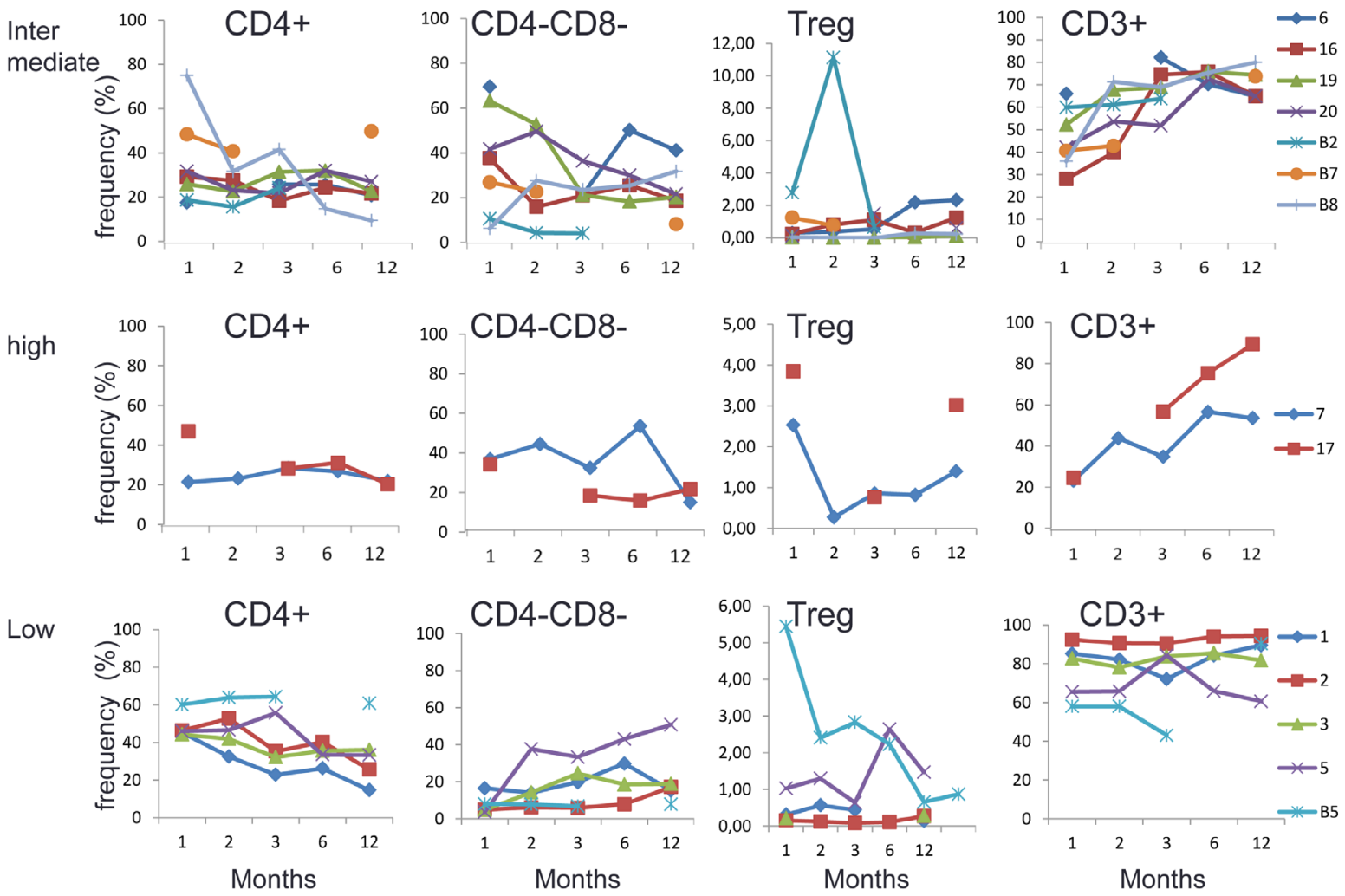

Figure 3: The frequency of CD4+ cell, CD4-CD8- (DN) $T$ cells, Treg cells and CD3+ cells and $\mathbf{T}_{\text {regs }}$ in $\mathbf{E B V}$ intermediate' $\mathrm{EBV}_{\text {low }}$ and $\mathrm{EBV} V_{\text {high }}$ groups in $1^{\text {st }}, 2^{\text {nd }}, 3^{\text {rd }}, 6^{\text {th }}$ and $12^{\text {th }}$ month after stem cell transplantation. Each curve represents one patient. Lines are not shown between dots with the same color when there are data missing between the dots. B2, B5, B7 and B8 are children and the remaining numbers refer to adult patients. B2, and 2, 7 and 17 represent non-survivors. 
EBV specific CD8+ and DN-cells were measured by labeled HLA- tetramers with specificity for latent and lytic EB viral proteins/antigens. In general, CD8+ and DN cells specific for lytic EBV antigen were more frequent than those with specificity to the latent antigen. Two cases illustrate different patterns of EBV DNA load in relation to reconstitution of EBV specific CD8+ and CD4-CD8- cells (Figure 4). In patient No.12, there was an initial high level of EBV specific T cells which then declined. Opposite the EBV load levels increased after three months peaking at 25780 copies $/ 10^{6} \mathrm{PBMC}$ after the 12 months. In contrast, patient No.31 had high levels of EBV specific CD8+ cells to the lytic viral antigen while the EBV DNA load seemed to be under control.

A

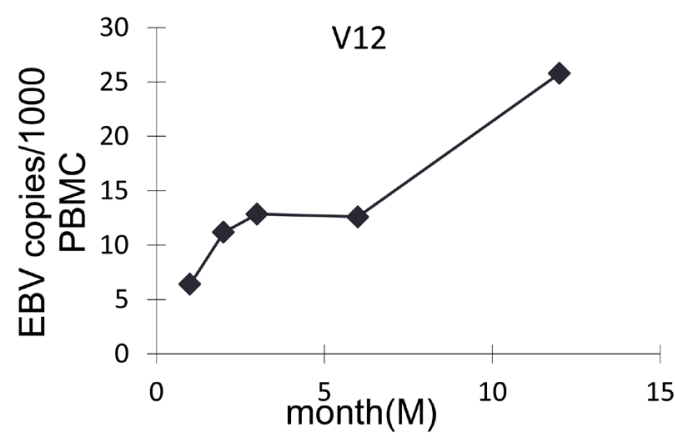

B
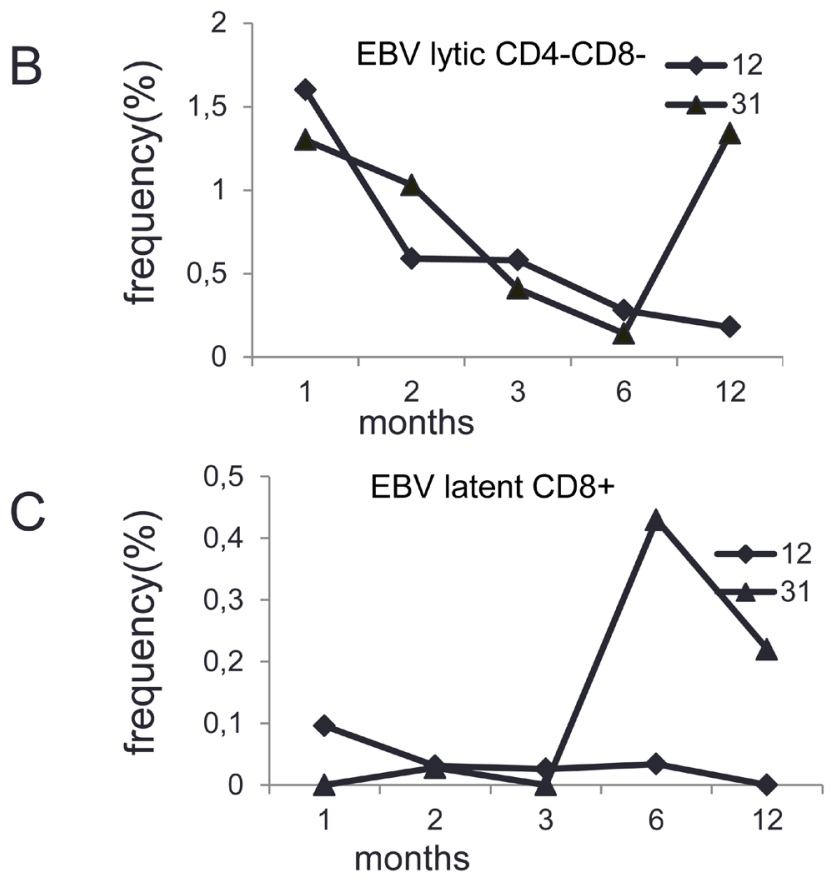

\section{DISCUSSION}

The crucial role of $\mathrm{T}$ cell mediated immune response in controlling the EBV persistent infection is emphasized by the consistent observation that patients with $\mathrm{T}$ cell dysfunction are at high risk of developing EBV-associated lymphoproliferative conditions [23, 24]. The EBV DNA levels - EBV load - in blood has been considered a marker which could reflect the functional status of the immune system. In stem cell transplanted patients, the immunosuppressive treatment affects the control of the latent EBV by the immune system. In addition the dramatic immune reconstitution from the donors stem cell transplant poses a stress to the immune system with a time window of immune imbalance early after transplantation.
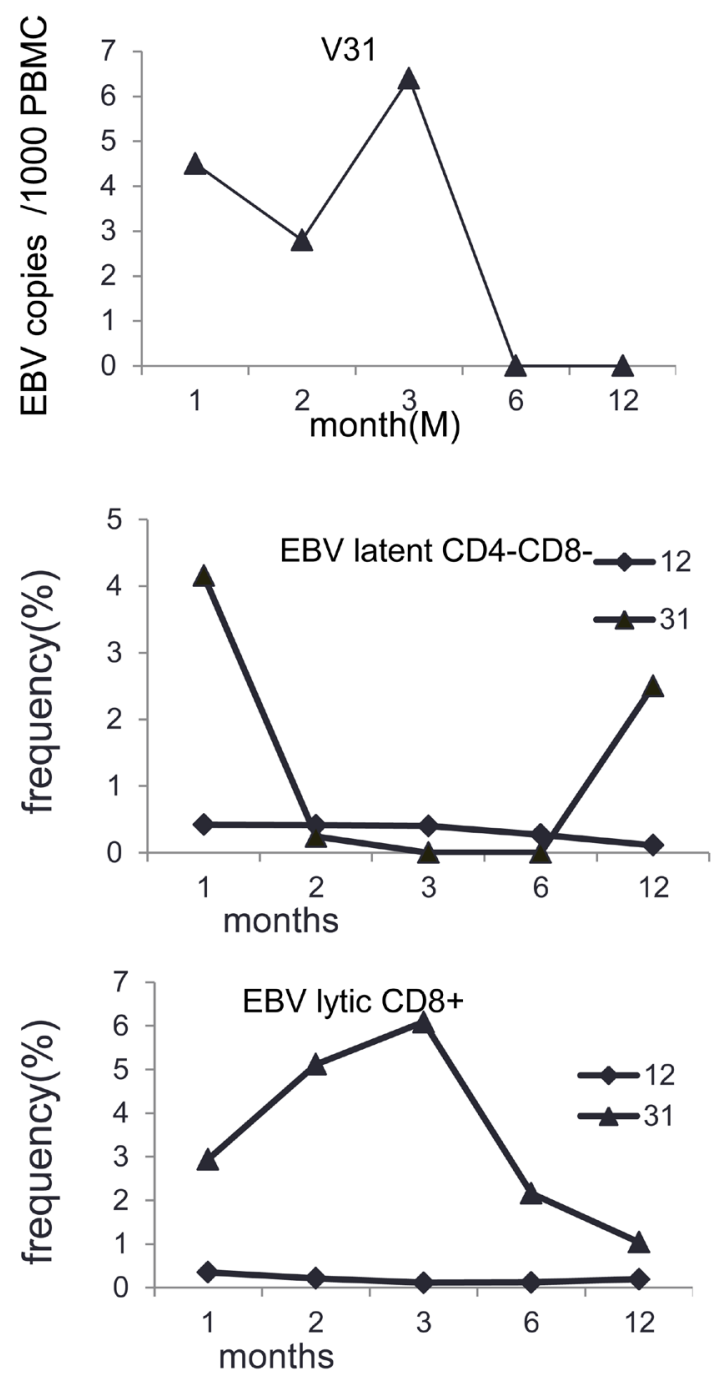

Figure 4: Analysis of EBV specific T cells in patients with different EBV DNA load dynamics. A. EBV load in adult patients No. 12 and No. 31 in $1^{\text {st }}, 2^{\text {nd }}, 3^{\text {rd }}, 6^{\text {th }}$ and $12^{\text {th }}$ month after stem cell transplantation. B. CD4-CD8- cells specific for lytic EBV antigens (left) and CD4-CD8- cells specific for latent EBV antigens (right) for the same patient at the same time points as in Fig4A. C. CD8+ cells specific for latent EBV antigens (left) and CD8+ cells specific for lytic EBV antigen (right) in the same patients at the same time points after stem cell transplantation as in Figure 4A. 
The EBV DNA load measured the way we do (cell-bound) is likely to reflect indirectly the number of circulating latently infected B-lymphocytes. From other studies we can conclude that there are few if any EBVinfected cells undergoing lytic virus replicayion in the peripheral blood, and we have earlier demonstrated that circulating infected B lymphocytes carry around five EBVgenomes/cell[25].

Viral infections are one common cause of death in SCT patients. Accumulated evidence suggests that high EBV DNA load is one biomarker predicting complications and poor survival. However, this is only true for whole groups, cohorts of high risk patients while correlations have been weak and virtually useless in the individual patient. The surprise from our unbiased analysis is that also low levels of EBV DNA load could be a marker for high risk of mortality. A low level of latent EBV infection during the immune reconstitution early after transplantation may result in an unbalanced control or homeostasis between the virus infection and the host immune system, due to e.g. low trigger/ boosting to establish or maintain efficient EBV immune control. Alternatively it might reflect adverse effects of immune suppression or stress of the immune system. The prognostic value of levels of EBV DNA load was enhanced by combination with clinical parameters linked to the conditioning, TBI, or immune suppression, the degree of acute GVHD. The identification of a high risk sub-group of post HSCT patients should put focus on this very specific group and lead to re-evaluation of aspects of conditioning, immune suppression and post-transplant follow up, e.g. the suggested medium-dose etoposide conditioning in SCT due to adult ALL may be more favorable than TBI [26].

The phenomenon of 'sneaking through' in tumor biology represents a parallel phenomenon to what we see here. This was described as the 'the preferential take of tumors after small size inocula to a similar degree with that seen with large size inocula, compared to the rejection of medium sized inocula' $[27,28]$. This phenomenon has been reported in several tumor systems [29] as 'a T cell dependent phenomenon.' [28]. As high and low EBV DNA load relates directly to the number of EBV carrying cells in peripheral blood, in effect this reflects the exposure of the immune system to high or low amounts of cell associated EBV antigens. This result could be interpreted as a result of high or low dose immune tolerance [30-32]. A correlate to what we observe may be that high EBV DNA levels are strongly associated with the development of post-transplant lymphoproliferative disease [4, 33]. Low EBV load has also in some studies been indicated as a predictor of a poor survival [34].

TBI plays an important role in SCT for both myeloablative regimens and reduced intensity conditioning regimens $[35,36]$. It is crucial to find a balanced TBI dose to eradicate the recipient marrow and/or reduce the tumor burden as much as possible and at the same time not to use a high dose that affects the reestablishment of the immune system and a functioning BM. Optimization of the 'magic dose' to achieve an ideal balanced treatment would be important. This depends on many factors, e.g., patient age, general condition, malignancy type and degrees, dose/rate/ fractionation of TBI, GVHD prophylaxis and stem cell source [36]. In our study, a higher dose of TBI (TBI $\geq 6$ Gy) alone was not significantly correlated to OS of the SCT patients, but together with EBV load and the degree of acute GVHD degree, it seems to be a clinical marker to predict poor overall survival.

We made another interesting observation. Two different patterns of dynamics of EBV DNA load were observed, those with a conspicuous peak of EBV load at 1-3 months post transplant which thereafter dropped to stabilize at a low/normal level during 6-12 months which we designated "type I" dynamics - and those which did not show this distinct early peak of EBV DNA load, but rather developed a variably high and often slowly increasing level of EBV load during 6 to 12 months "type II". Originally we hypothesized that there would be a difference in clinical outcome between the patients with these two different patterns of EBV load dynamics. We were unable to establish the significance of such a relation, but so far we have had too few patients with the $2^{\text {nd }}$ type of pattern to possibly reach any significance. One problem with this hypothesis was patients who died early within 6 months after the SCT were then excluded due to that the EBV load could not be followed for longer time up to 12 months. Thus these short term survivors were a priori excluded in our classification of the EBV dynamic patterns. After this failing hypothesis - so far - we decided to use the early levels of EBV DNA load as a basis of grouping patients, which thus also came to include those with the worst outcome according to our analysis.

The limitations of our study are that there are relatively few patients included with different types of donors, different sources of grafts, different types of diagnoses, conditioning, some patients were treated with ATG and others were not, and different types of immunosuppressive prophylaxis was given. Therefore, the findings have to be taken with caution. However, despite these shortcomings, EBV adds a significant impact on survival and the patients with three defined risk-factors had an extremely poor outcome. EBV load may be a surrogate marker for defining patients with poor immune reconstitution after HSCT. Such patients may be at risk to acquire other infections. For instance, these patients may more often have concomitant reactivation of cytomegalovirus (CMV), which has additional immunosuppressive effect [37]. Patients with CMV infections also have an increased risk of bacterial and invasive fungal infection after HSCT [38]. Earlier we have suggested EBV as a good surrogate marker for immune reconstitution after cART treatment in HIV patients [39, 
40]. Our data suggest that cell-bound EBV DNA load is an interesting reflection of the quality and balance of reestablishing the immune system. Moderate levels of EBV DNA load, reflects a balanced reconstitution, the parameters of which now should be better established. This will require larger sample size and extensive immune-phenotyping.

\section{MATERIALS AND METHODS}

\section{Patients}

The characteristics of the patients are summarized in Table 1. Blood samples were collected from the patients at 1, 2, 3, 6 and 12 months after HSCT. Fifty-one patients were included, with blood samples from all the three early time points, one, two and three months. Seventeen were children ( $\leq 18$ years old) and 34 were adults. Forty-nine of these underwent HSCT due to malignant disorders. Thirtytwo patients received grafts from matched unrelated donors (MUD), seven from HLA-mismatched unrelated donors (MM) and 12 from HLA-identical siblings. Four had a mismatch of EBV status between donor and recipient, one with an EBV negative donor and the other three were EBV negative recipients, as determined by EBV serology. The sources of stem cells were either peripheral blood stem cells (PBSC, $n=39$ ), bone marrow $(\mathrm{BM}, n=9)$ or umbilical cord blood $(\mathrm{CB}, n=3)$.

\section{Ethics statement}

The study was approved by the Stockholm Ethical Committee South 2010/760-31/1. In the case of children consent was also obtained from parents or legal guardians (on file at Center for Allogeneic Stem Cell transplantation, CAST, Karolinska University Hospital, Huddinge).

\section{Conditioning for the HSCT regimen}

The details of conditioning and post-transplant supportive care have been reported elsewhere [1, 41, 42].

Conventional myeloablative conditioning was given to 31 patients and consisted of cyclophosphamide $(\mathrm{Cy})$ at $60 \mathrm{mg} / \mathrm{kg}$ for two days in combination with fractionated TBI (FTBI) at $3 \mathrm{~Gy} /$ day for four days $(n=8)$, or busulphan $(\mathrm{Bu})$ at $4 \mathrm{mg} / \mathrm{kg} /$ day for four days $(n=16)$, or $\mathrm{Bu}$ and melphalan $140 \mathrm{mg} / \mathrm{m}^{2}(n=3)(20)$. Three patients received FTBI and vepecide $60 \mathrm{mg} / \mathrm{kg}$ and one patient received fludarabin (Flu) at $30 \mathrm{mg} / \mathrm{m}^{2}$ for 4 days in combination with $\mathrm{Bu}$ at $4 \mathrm{mg} / \mathrm{kg} /$ day for two days and thithepa $20 \mathrm{mg} /$ $\mathrm{kg}$. Reduced-intensity conditioning (RIC) was given to 20 patients and consisted of Flu at $30 \mathrm{mg} / \mathrm{m}^{2}$ for 3-6 days in combination with either $\mathrm{Bu}$ at $4 \mathrm{mg} / \mathrm{kg} /$ day for two days (n
$=5)$, FTBI at $3 \mathrm{~Gy} /$ day for two days and Cy at $60 \mathrm{mg} / \mathrm{kg}$ / day for two days $(n=6)$, Cy at $30 \mathrm{mg} / \mathrm{kg} /$ day for two days $(n=1)$, treosulphan at $12-14 \mathrm{~g} / \mathrm{m}^{2} /$ day for 3 days $(n=7)$, or TBI (2 Gy) $(n=1)$.

\section{Purification of peripheral blood mononuclear cells}

The purification of PBMCs has been described elsewhere [1, 41]. Briefly, five to $10 \mathrm{ml}$ of blood were collected from all patients starting from the fourth week after BMT and then at 2, 3, 6 and 12 months after transplantation. PBMCs were isolated by separating heparinized blood on a Ficoll Hypaque gradient (Amersham Pharmacia, Uppsala, Sweden). The cells were preserved in fetal bovine serum (FBS) containing 10\% DMSO a $-160^{\circ} \mathrm{C}$. Aliquots of PBMCs were thawed and used for analysis of lymphocyte subsets by 12-color flow cytometry and for preparation of DNA for determination of EBV-DNA genome and analysis of viral gene expression.

\section{DNA extraction and EBV load measurement}

DNA was extracted and purified by QIAamp DNA Mini Kit (QIAGEN GmbH, Germany) according to the manufacturer's instruction. The concentration of the purified DNA was measured using NanoDrop ND-1000 spectrophotometer.

The qPCR assay was performed according to Kimura et al [43]. Briefly DNA from the EBV positive Burkitt's lymphoma Namalwa cell line was used to establish a standard curve. The primers for PCR were from the BALF5 EBV gene encoding the viral DNA polymerase [44] The EBV unique upstream and downstream primer sequences were 5'-CGGAAGCCCTCTGGACTTC-3' and 5'-CCCTGTTTATCCGATGGAATG-3', respectively (Life Technologies Europe ,Stockholm, Sweden). Fluorogenic probe for BALF5 (5'-TGTACACGCACGAGAAATGCGCC-3') and for Albumin (5' CCTGTCATGCCCACACAAATCTCTCC $\left.-3^{\prime}\right)$ with a sequence located between the PCR primers respectively were synthesized by PE Applied Biosystems (Foster City, USA.). Taqman genotyping master mix was applied (Applied Biosystems, Foster City, USA). The PCR reaction was performed in MicroAmp optical 96well reaction plate (Applied Biosystems, Singapore) with MicroAmp optical adhesive film (Applied Biosystem, Foster City, USA). Real-time fluorescence measurements were performed on a 7500 Sequence Detector (PE Applied Biosystems). Albumin was used as an internal control.

\section{Flow cytometry}

The analysis of PBMCs was also described previously [41]. Frozen PBMCs from were thawed and 
$1 \times 10^{6}$ cells were incubated at $4^{\circ} \mathrm{C}$ for $15 \mathrm{~min}$ with the following antibodies: PerCP conjugated anti-CD3 (SK7), APC-Cy7- conjugated anti-CD8 $\alpha$ chain (SK1) purchased from BD Biosciences (Stockholm, Sweden), Krome Orange-conjugated anti-CD4 (13B8.2), FiTC-conjugated anti-CD8 $\beta$ chain (2ST8.5H7), as well as antibodies to CD25hi, Foxp3 and CD127 were purchased from Beckman Coulter (Marseille, France). After washing with $1 \mathrm{~mL}$ of PBS containing $0.1 \%$ BSA, the cell pellet was resuspended in $200 \mu \mathrm{l}$ of PBS (with $0.1 \%$ BSA) and the cells were analyzed by flow cytometric with Navios flow cytometer (Beckman Coulter, Miami, FL, USA) and data analysis was done with software FlowJo (Tree Star Inc., Ashland, OR; USA).

\section{Grouping according to the EBV load}

After determination of EBV DNA levels the patients were divided into two groups: those with intermediate levels of EBV DNA load and those with high or low. The border values between the groups were chosen arbitrarily based on the data, as follows: high EBV load was defined as higher than 90000 copies $/ 10^{6} \mathrm{PBMC}$ in at least one of the three samples, or higher than 60000 copies $/ 10^{6} \mathrm{PBMC}$ in at least two of the three samples of the PBMCs collected at one, two and three months after the transplantation. Low EBV load was defined as a genome copy number below 6000 copies $/ 10^{6} \mathrm{PBMC}$ in all the three samples, or negative in at least 2 of the 3 samples. These high or low EBV load groups have then been treated as one group: the $\mathrm{EBV}_{\text {high+low }}$ group. The remaining cases were defined to have intermediate EBV load ( $\left.\mathrm{EBV}_{\text {intermediate }}\right)$.

\section{Tetramers for analysis of EBV-specific T cells}

Tetramer-guided analysis of EBV-specific T cells was carried out as described earlier [1, 45]. In brief, frozen PBMCs were thawed, washed and incubated with tetramers at $37^{\circ} \mathrm{C}$ for $30 \mathrm{~min}$. The PE labelled HLA-A*0201 tetramers for EBV BMLF-1 (GLCTLVAML) and LMP-2 (CLGGLLTMV) and HLA-A*24 tetramers for BRFL1 (DYCNVLNKEF) and EBNA-3 (RYSIFFDY) were applied (Beckman Coulter). The cells were washed with staining buffer (PBS with 2\% FCS) and incubated at $4^{\circ}$ $\mathrm{C}$ for $15 \mathrm{~min}$ with monoclonal antibodies for cell surface markers, PerCP-conjugated anti-TCR[alpha][beta] (WT31; BD Biosciences), APC-Alexa-Fluor 750-conjugated antiCD8[alpha] chain (T8; Beckman Coulter) and Pacific Blue conjugated anti-CD4 ( Beckman Coulter). The cells were then washed, re-suspended in staining buffer and data acquisition was performed by FACSAria Flow cytometer (BD Biosciences). Finally the data was analyzed with the software FlowJo (Tree Star Inc., Ashland, OR).

\section{Statistics}

Overall survival was calculated using the KaplanMeier method and compared with the log-rank test. Uniand multivariate analysis of factors associated to survival was performed with the Cox proportional hazards model. Factors with a $P$-value $<0.2$ in the univariate analysis were included in the backwards elimination multivariate analysis. Factors analyzed are displayed in Table 2. Continuous variables were compared with the MannWhitney test and categorical variables with the Fisher exact test. Analysis was performed with the Statistica software (Statsoft, Tulsa, MN, USA).

\section{GRANT SUPPORT}

This study was supported by grants from Swedish Cancer Society, Children's Cancer Foundation, $\mathrm{CaF} /$ GV jubilee foundation, and Math O Sundqvist family foundation.

\section{CONFLICTS OF INTEREST}

The authors declare no conflict of interest.

\section{REFERENCES}

1. Ahmed RK, Poiret T, Ambati A, Rane L, Remberger M, Omazic B, Vudattu NK, Winiarski J, Ernberg I, AxelssonRobertson R, Magalhaes I, Castelli C, Ringden $\mathrm{O}$ and Maeurer M. TCR+CD4-CD8- T cells in antigen-specific MHC class I-restricted T-cell responses after allogeneic hematopoietic stem cell transplantation. J Immunother. 2014; 37:416-425.

2. Uhlin M, Wikell H, Sundin M, Blennow O, Maeurer M, Ringden O, Winiarski J, Ljungman P, Remberger $\mathrm{M}$ and Mattsson J. Risk factors for Epstein-Barr virus-related post-transplant lymphoproliferative disease after allogeneic hematopoietic stem cell transplantation. Haematologica. 2014; 99:346-352.

3. Heslop HE and Rooney CM. Adoptive cellular immunotherapy for EBV lymphoproliferative disease. Immunol Rev. 1997; 157:217-222.

4. Dierickx D, Tousseyn T and Gheysens O. How we diagnose and treat posttransplant lymphoproliferative disorders. Blood. 2015; 126:2274-83.

5. Dolcetti R, Dal Col J, Martorelli D, Carbone A and Klein E. Interplay among viral antigens, cellular pathways and tumor microenvironment in the pathogenesis of EBV-driven lymphomas. Semin Cancer Biol. 2013; 23:441-456.

6. Klein E, Kis LL and Klein G. Epstein-Barr virus infection in humans: from harmless to life endangering viruslymphocyte interactions. Oncogene. 2007; 26:1297-1305.

7. Steven NM, Leese AM, Annels NE, Lee SP and Rickinson 
AB. Epitope focusing in the primary cytotoxic $T$ cell response to Epstein-Barr virus and its relationship to $\mathrm{T}$ cell memory. J Exp Med. 1996; 184:1801-1813.

8. Yao QY, Tierney RJ, Croom-Carter D, Dukers D, Cooper GM, Ellis CJ, Rowe M and Rickinson AB. Frequency of multiple Epstein-Barr virus infections in T-cellimmunocompromised individuals. J Virol. 1996; 70:48844894.

9. Ressing ME, van Gent M, Gram AM, Hooykaas MJ, Piersma SJ and Wiertz EJ. Immune Evasion by EpsteinBarr Virus. Curr Top Microbiol Immunol. 2015; 391:355381.

10. Nagy N, Adori M, Rasul A, Heuts F, Salamon D, Ujvari D, Madapura HS, Leveau B, Klein G and Klein E. Soluble factors produced by activated CD4+ T cells modulate EBV latency. Proc Natl Acad Sci U S A. 2012; 109:1512-1517.

11. Hanto DW, Frizzera G, Gajl-Peczalska KJ and Simmons RL. Epstein-Barr virus, immunodeficiency, and B cell lymphoproliferation. Transplantation. 1985; 39:461-472.

12. Nalesnik MA, Jaffe R, Starzl TE, Demetris AJ, Porter K, Burnham JA, Makowka L, Ho M and Locker J. The Pathology of Posttransplant Lymphoproliferative Disorders Occurring in the Setting of Cyclosporine a-Prednisone Immunosuppression. Am J Pathol. 1988; 133:173-192.

13. Liu Q, Xuan L, Liu H, Huang F, Zhou H, Fan Z, Zhao K, Wu M, Xu L, Zhai X, Zhang F, Liu C, Sun J and Huang $\mathrm{X}$. Molecular monitoring and stepwise preemptive therapy for Epstein-Barr virus viremia after allogeneic stem cell transplantation. Am J Hematol. 2013; 88:550-555.

14. Gustafsson A, Levitsky V, Zou JZ, Frisan T, Dalianis $\mathrm{T}$, Ljungman $\mathrm{P}$, Ringden O, Winiarski J, Ernberg I and Masucci MG. Epstein-Barr virus (EBV) load in bone marrow transplant recipients at risk to develop posttransplant lymphoproliferative disease: prophylactic infusion of EBV-specific cytotoxic T cells. Blood. 2000; 95:807-814.

15. Stevens SJ, Pronk I and Middeldorp JM. Toward standardization of Epstein-Barr virus DNA load monitoring: unfractionated whole blood as preferred clinical specimen. J Clin Microbiol. 2001; 39:1211-1216.

16. Ruf S and Wagner HJ. Determining EBV load: current best practice and future requirements. Expert Rev Clin Immunol. 2013; 9:139-151.

17. Tsai DE, Douglas L, Andreadis C, Vogl DT, Arnoldi S, Kotloff R, Svoboda J, Bloom RD, Olthoff KM, Brozena SC, Schuster SJ, Stadtmauer EA, Robertson ES, Wasik MA and Ahya VN. EBV PCR in the diagnosis and monitoring of posttransplant lymphoproliferative disorder: results of a two-arm prospective trial. Am J Transplant. 2008; 8:10161024.

18. Bakker NA, Verschuuren EA, Erasmus ME, Hepkema BG, Veeger NJ, Kallenberg CG and van der Bij W. Epstein-Barr virus-DNA load monitoring late after lung transplantation: a surrogate marker of the degree of immunosuppression and a safe guide to reduce immunosuppression. Transplantation. 2007; 83:433-438.

19. Michelson P, Watkins B, Webber SA, Wadowsky R and Michaels MG. Screening for PTLD in lung and heart-lung transplant recipients by measuring EBV DNA load in bronchoalveolar lavage fluid using real time PCR. Pediatr Transplant. 2008; 12:464-468.

20. Calabrese F, Loy M, Lunardi F, Marino D, Aversa SM and Rea F. Acute cellular rejection and Epstein-Barr virusrelated post-transplant lymphoproliferative disorder in a pediatric lung transplant with low viral load. Transpl Infect Dis. 2010; 12:342-346.

21. Jimenez S. Epstein-Barr virus-associated posttransplantation lymphoproliferative disorder: potential treatments and implications for nursing practice. Clin J Oncol Nurs. 2015; 19:94-98.

22. Luskin MR, Heil DS, Tan KS, Choi S, Stadtmauer EA, Schuster SJ, Porter DL, Vonderheide RH, Bagg A, Heitjan DF, Tsai DE and Reshef R. The Impact of EBV Status on Characteristics and Outcomes of Posttransplantation Lymphoproliferative Disorder. Am J Transplant. 2015; 15:2665-2673.

23. Mautner J and Bornkamm GW. The role of virus-specific CD4+ T cells in the control of Epstein-Barr virus infection. Eur J Cell Biol. 2012; 91:31-35.

24. Nowakowska J, Stuehler C, Egli A, Battegay M, Rauser G, Bantug GR, Brander C, Hess C and Khanna N. T cells specific for different latent and lytic viral proteins efficiently control Epstein-Barr virus-transformed B cells. Cytotherapy. 2015; 17:1280-1291.

25. Ehlin-Henriksson B, Zou JZ, Klein G and Ernberg I. Epstein-Barr virus genomes are found predominantly in IgA-positive B cells in the blood of healthy carriers. Int $\mathrm{J}$ Cancer. 1999; 83:50-54.

26. Imamura $M$ and Shigematsu A. Allogeneic hematopoietic stem cell transplantation in adult acute lymphoblastic leukemia: potential benefit of medium-dose etoposide conditioning. Exp Hematol Oncol. 2015; 4:20.

27. Klein G. Recent trends in tumor immunology. Isr J Med Sci. 1966; 2:135-142.

28. Gatenby PA, Basten A and Creswick P. "Sneaking through": a T-cell-dependent phenomenon. Br J Cancer. $1981 ; 44: 753-756$.

29. Naor D. Suppressor cells: permitters and promoters of malignancy? Adv Cancer Res. 1979; 29:45-125.

30. Swinton J, Schweitzer AN and Anderson RM. Two signal activation as an explanation of high zone tolerance: a mathematical exploration of the nature of the second signal. J Theor Biol. 1994; 169:23-30.

31. Stumpf R, Heuer J and Kolsch E. Suppressor T cells in low zone tolerance. I. Mode of action of suppressor cells. Eur J Immunol. 1977; 7:74-85.

32. Heuer J, Stumpf R, Kolsch E, Shen FW and Hammerling GJ. Suppressor $\mathrm{T}$ cells in low zone tolerance. II. 
Characterization of suppressor $\mathrm{T}$ and amplifier cells by physical and serological methods. Eur J Immunol. 1977; 7:769-775.

33. Aalto SM, Juvonen E, Tarkkanen J, Volin L, Haario H, Ruutu $\mathrm{T}$ and Hedman K. Epstein-Barr viral load and disease prediction in a large cohort of allogeneic stem cell transplant recipients. Clin Infect Dis. 2007; 45:1305-1309.

34. Auger S, Orsini M, Ceballos P, Fegueux N, Kanouni $\mathrm{T}$, Caumes B, Klein B, Villalba $\mathrm{M}$ and Rossi JF. Controlled Epstein-Barr virus reactivation after allogeneic transplantation is associated with improved survival. Eur J Haematol. 2014; 92:421-428.

35. Hill-Kayser CE, Plastaras JP, Tochner Z and Glatstein E. TBI during BM and SCT: review of the past, discussion of the present and consideration of future directions. Bone Marrow Transplant. 2011; 46:475-484.

36. Adkins DR and DiPersio JF. Total body irradiation before an allogeneic stem cell transplantation: is there a magic dose? Curr Opin Hematol. 2008; 15:555-560.

37. Paulin T, Ringden $\mathrm{O}$ and Lonnqvist B. Faster immunological recovery after bone marrow transplantation in patients without cytomegalovirus infection. Transplantation. 1985; 39:377-384.

38. Paulin T, Ringden O, Nilsson B, Lonnqvist B and Gahrton G. Variables predicting bacterial and fungal infections after allogeneic marrow engraftment. Transplantation. 1987; 43:393-398.

39. Friis AM, Akerlund B, Gyllensten K, Aleman A, Bratt G, Sandstrom E and Ernberg I. Epstein-Barr virus genome load is increased by therapeutic vaccination in HIV-1 carriers, and further enhanced in patients with a history of symptomatic primary infection. Vaccine. 2012; 30:60936098.
40. Friis AM, Gyllensten K, Aleman A, Ernberg I and Akerlund B. The Effect of Antiretroviral Combination Treatment on Epstein-Barr Virus (EBV) Genome Load in HIV-Infected Patients. Viruses. 2010; 2:867-879.

41. Poiret T, Rane L, Remberger M, Omazic B, GustafssonJernberg A, Vudattu NK, Ahmed R, Ernberg I, Winiarski J, Magalhaes I, Ringden $O$ and Maeurer M. Reduced plasma levels of soluble interleukin-7 receptor during graftversus-host disease (GVHD) in children and adults. BMC Immunol. 2014; 15:25.

42. Svahn BM, Remberger M, Myrback KE, Holmberg K, Eriksson B, Hentschke P, Aschan J, Barkholt L and Ringden $\mathrm{O}$. Home care during the pancytopenic phase after allogeneic hematopoietic stem cell transplantation is advantageous compared with hospital care. Blood. 2002; 100:4317-4324.

43. Kimura H, Morita M, Yabuta Y, Kuzushima K, Kato K, Kojima S, Matsuyama T and Morishima T. Quantitative analysis of Epstein-Barr virus load by using a real-time PCR assay. J Clin Microbiol. 1999; 37:132-136.

44. Baer R, Bankier AT, Biggin MD, Deininger PL, Farrell PJ, Gibson TJ, Hatfull G, Hudson GS, Satchwell SC, Seguin $\mathrm{C}$ and et al. DNA sequence and expression of the B95-8 Epstein-Barr virus genome. Nature. 1984; 310:207-211.

45. Jager E, Maeurer M, Hohn H, Karbach J, Jager D, Zidianakis Z, Bakhshandeh-Bath A, Orth J, Neukirch C, Necker A, Reichert TE and Knuth A. Clonal expansion of Melan A-specific cytotoxic T lymphocytes in a melanoma patient responding to continued immunization with melanoma-associated peptides. Int J Cancer. 2000; 86:538547. 